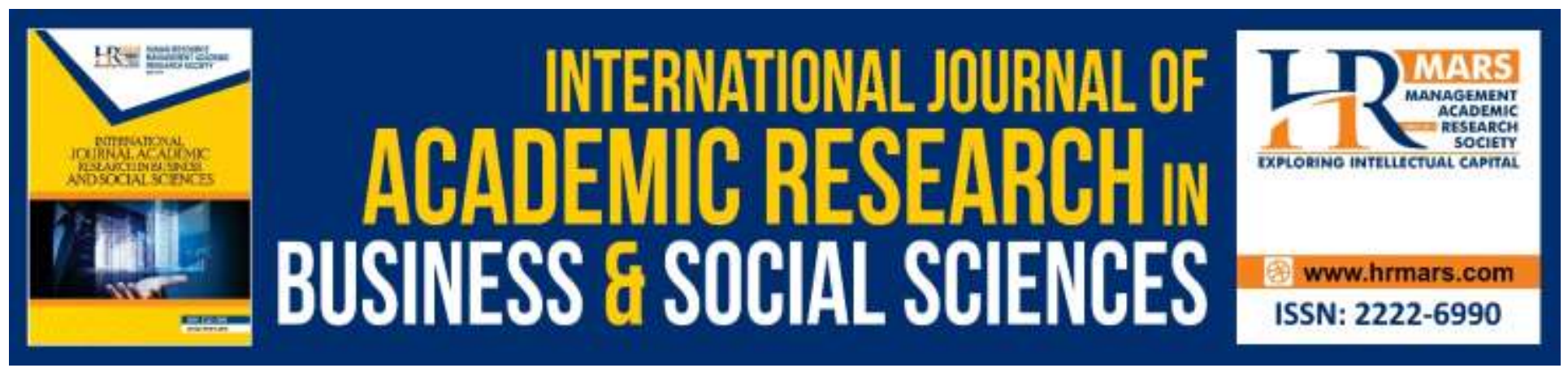

\title{
Engaging and Helping Seniors: The Case of the Pioneer Generation Ambassadors in Singapore
}

\author{
Intan Azura Mokhtar
}

To Link this Article: http://dx.doi.org/10.6007/IJARBSS/v10-i2/6942

DOI:10.6007/IJARBSS/v10-i2/6942

Received: 03 January 2020, Revised: 28 January 2020, Accepted: 02 February 2020

Published Online: 19 February 2020

In-Text Citation: (Mokhtar, 2020)

To Cite this Article: Mokhtar, I. A. (2020). Engaging and Helping Seniors: The Case of the Pioneer Generation Ambassadors in Singapore. International Journal of Academic Research in Business and Social Sciences, 10(2), 439-451.

Copyright: (C) 2020 The Author(s)

Published by Human Resource Management Academic Research Society (www.hrmars.com)

This article is published under the Creative Commons Attribution (CC BY 4.0) license. Anyone may reproduce, distribute, translate and create derivative works of this article (for both commercial and non-commercial purposes), subject to full attribution to the original publication and authors. The full terms of this license may be seen at: http://creativecommons.org/licences/by/4.0/legalcode

Vol. 10, No. 2, 2020, Pg. 439 - 451

Full Terms \& Conditions of access and use can be found at http://hrmars.com/index.php/pages/detail/publication-ethics 


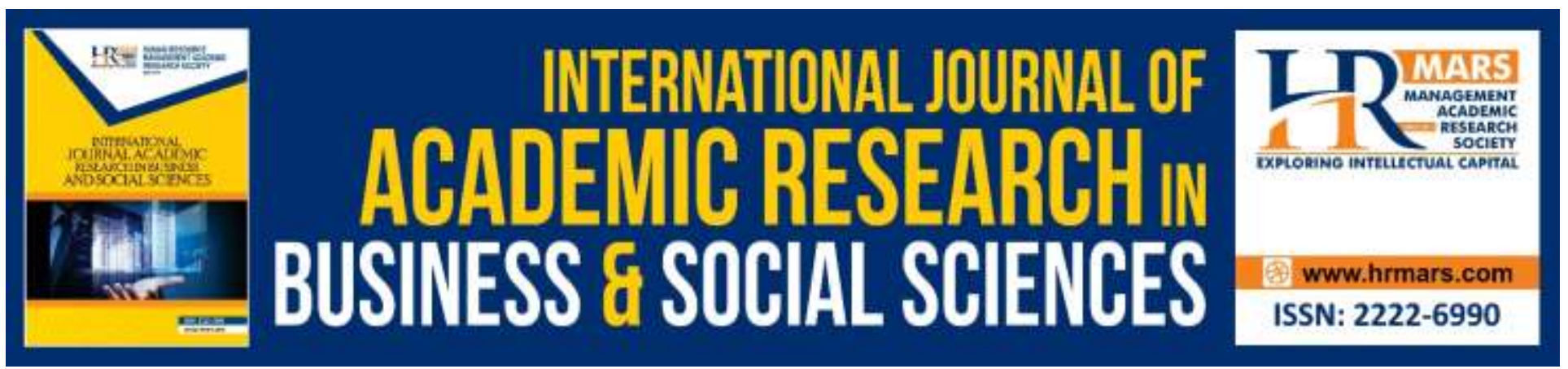

\title{
Engaging and Helping Seniors: The Case of the Pioneer Generation Ambassadors in Singapore
}

\author{
Intan Azura Mokhtar \\ Singapore Institute of Technology, Singapore
}

\begin{abstract}
Singapore, a young and modern city-state in Southeast Asia, is home to more than 5.6 million people, with about 3.5 million Singapore citizens. About $10 \%$ or 550,000 of its residents are 65 years old and above, while the country's Total Fertility Rate is rather low at 1.14. Both of these statistical data indicate that Singapore is an increasingly ageing population. Singapore takes on a whole-ofgovernment approach to ensure the country is ready to support seniors and an increasingly ageing population. Legislation and policies are constantly reviewed and changed to help Singaporeans remain employable and employed for longer; numerous health-related programs and initiatives are put in place to ensure active and healthy ageing; and amenities and infrastructure are constantly upgraded to make housing estates and public places more friendly and ready for seniors. Other than legislation, policies, programs and infrastructure, one other important aspect of this whole-ofgovernment approach is the human touch and personal communication. The Pioneer Generation Office (PGO), initially set up in 2014 to reach out to and explain the Singapore government's S\$9 billion Pioneer Generation Package, has since expanded its scope of work and objectives to include outreach to, engagement and befriending of all seniors in Singapore. This paper presents a case study of the PGO through the lens of its Chief Training Officer, as she was tasked with overseeing the training, development and readiness of the Pioneer Generation Ambassadors (PGAs) in order to prepare them to carry out their outreach and engagement initiatives to seniors in Singapore.
\end{abstract}

\section{Introduction}

Lee Hui Ying (not her real name) was the Chief Training Officer (CTO) in the Pioneer Generation Office (PGO), Singapore. As the CTO, Hui Ying was tasked to oversee the training, development and readiness of the Pioneer Generation Ambassadors (PGAs) before they were able to carry out their outreach and engagement initiatives to seniors in Singapore. While the training and development program for the PGAs had been set out clearly and had managed to train more than 3,000 PGAs, Hui Ying faced the current challenges of (i) having had only 1,300 trained PGAs left to carry out the outreach initiatives to seniors; (ii) recruiting, training and retaining more potential PGAs; and (iii) recruiting younger individuals to be trained and retained as PGAs. 
With the scope of work by the PGAs expanded to include outreach, extending care, and making referrals for relevant follow-ups by the various social service agencies or ministry departments, the PGO was in urgent need of appropriately trained PGAs to do these important groundwork and legwork to both the 450,000 pioneers (those aged 65 years old and above as at Dec 2014), and the 100,000 seniors (those aged 60 years old and above as at Dec 2014). While technological tools might have alleviated part of this need, the challenge therein was that the majority of the seniors in Singapore were not technologically savvy, despite Singapore being one of the most networked countries with a high internet penetration rate. In addition, with consistent policy and legislative changes involving seniors, there was a genuine concern by the government that this group of Singaporeans would be left behind in terms of getting the assistance they required or in understanding these changes that would affect their lives or the lives of those close to them.

Hence, the work of the PGAs was all the more important as they were needed to explain current senior-related government policies and schemes to these seniors. This last-mile outreach, engagement and follow-up was important in ensuring that the senior were aware of what packages, programs or schemes they were eligible for, and should they need other forms of assistance, the PGAs would have to go the extra mile and refer them to the relevant agencies, such as the Agency for Integrated Care (AIC) or the Social Service Office (SSO), to be followed up with.

Hui Ying resolved that in order to be able to meet the urgent demand for PGAs, she would need some help. She decided to explore collaborations with the institutions of higher learning to get collegelevel students to be trained and deployed as PGAs, as well as work with government agencies, and grassroots and volunteer organizations to form a collaborative network of befrienders and to engage senior Singaporeans from among their existing pool of personnel and volunteers. However, Hui Ying was uncertain of how successful these strategies would be in recruiting and retaining the required PGAs, and in maintaining and extending the outreach to, engagement of and follow up with senior Singaporeans in order to help them age happily, healthily and actively for as long as they lived.

\section{The Global Ageing Population}

The 2015 United Nations report on World Population Ageing stated clearly that the world is ageing (UN DESA, 2015, p.1). The report claimed that "according to data from World Population Prospects: the 2015 Revision (United Nations, 2015), the number of older persons-those aged 60 years or overhas increased substantially in recent years in most countries and regions, and that growth is projected to accelerate in the coming decades."

Among the statistics shared in the report were:

- Between 2015 and 2030, the number of people in the world aged 60 years and above is projected to grow by 56 per cent, from 901 million to 1,400 million, and by 2050, the global population of these older persons is projected to more than double its size in 2015 , reaching nearly 2,100 million. 
INTERNATIONAL JOURNAL OF ACADEMIC RESEARCH IN BUSINESS AND SOCIAL SCIENCES Vol. 10, No. 2, Feb, 2020, E-ISSN: 2222-6990 @ 2020 HRMARS

- Globally, the number of people aged 80 years and above (the "oldest-old" persons) is growing even faster than the number of older persons overall. Projections indicate that in 2050 the oldest-old will number 434 million, having more than tripled in number since 2015, when there were 125 million people over the age of 80 .

- The older population is growing faster in urban areas than in rural areas. At the global level between 2000 and 2015, the number of people aged 60 years and above increased by 68 per cent in urban areas, compared to a 25 per cent increase in rural areas. As a result, older persons are increasingly concentrated in urban areas. In 2015, 58 per cent of the world's people aged 60 years or over resided in urban areas, up from 51 per cent in 2000 . The oldestold are even more likely to reside in urban areas: the proportion of people aged 80 years or over residing in urban areas increased from 56 per cent in 2000 to 63 per cent in 2015.

In the report, several countries were identified to have a larger proportion of those aged 60 years old and above, and that the ageing process was seemingly more advanced in high-income countries such as Japan, Germany, Italy and Finland. In 2015, Japan was home to the world's most aged population, with about 33 percent of Japanese aged 60 years old and above. This was followed by Germany and Italy (28 percent each), and Finland (27 percent).

Population ageing in itself should not be seen as a problem. In fact, population ageing is a demographic success story that came about as a result of changes in fertility, mortality, and access to amenities and other public goods (Crampton. 2009, p.4). For instance, better access to healthcare, family planning, proper sanitation and clean water, have significantly reduced child and maternal mortality, but also contributed to reductions in birth rates. Advancements in medical research and technologies, medicine, healthcare, as well as better nutrition and access to education and employment opportunities, have allowed people to live longer and lead healthier lives in general.

Taken together, the declines in fertility, reduced mortality, and increased longevity, mean that generally the proportion of younger persons is decreasing compared to the proportion of older persons.

It has also been found that among the young people today, lifespans to the age of 80 years old is expected to be the norm (Easterbrook, 2014). Globally, 60 percent of women and 52 percent of men born between the years 2000 to 2005 are expected to survive to their $80^{\text {th }}$ birthdays, compared to less than 40 percent of both women and men born between the years 1950 to 1955 (50 years ago).

For many countries, the number of older people is growing much faster than the number of economically active people (those of traditional working ages). This has led many governments to consider increasing the statutory retirement age in an effort to (i) prolong the labor force participation of older people; (ii) strengthen the financial stability of pension systems and financial assistance schemes; and (iii) help older people stay active longer in a bid to prevent the early onset of age-related conditions such as dementia, Alzheimer's disease and osteoarthritis (Ross, 2010; Staudinger, Finkelstein, Calvo and Sivaramakrishnan, 2016; Mulders, 2019; Zacher, Kooji and Beier, 
INTERNATIONAL JOURNAL OF ACADEMIC RESEARCH IN BUSINESS AND SOCIAL SCIENCES Vol. 10, No. 2, Feb, 2020, E-ISSN: 2222-6990 @ 2020 HRMARS

2018). Population ageing and the growth in the number of older persons place substantial pressure on health systems and the demand for care, services and technologies to treat non-communicable and chronic conditions associated with old age. In addition, it has been found that social exclusion where the older person is left to their own devices, resources and means - contributes to visible signs of ageing, incidence of chronic illnesses, and social and health inequalities among older persons (Latimer, Davis, Bagley and Kipling, 2011; Zacher and Rudolph, 2017). Hence, it becomes imperative for older people to be physically active, economically active, mentally active and socially included.

\section{Singapore's population challenges - babies and seniors}

Singapore is a relatively young nation, having been thrusted to independence and self-government in 1965. Prior to its independence in 1965, Singapore had a population of about 1 million residents (Koh, 2010). Soon after independence, Singapore's population grew because of natural births compared to migration. The Total Fertility Rate (TFR) in 1957 was 6.56 while the TFR dropped to 4.62 in 1965 (independence). However, the government of the day then felt that the TFR of more than 4.0 was still too high and would take a toll on the country's resources, which were quite scarce, it being a newly independent nation. As a result, the government set up the Singapore Family Planning and Population Board in 1966, to manage the nation's population growth and encourage smaller families, in light of many uncertainties facing the young nation.

Singapore prospered over the years due to a stable government, prudent fiscal policies, long-term planning, and the government's push for investments in the country. However, the TFR continued to decrease, as a result of a better educated populace, greater awareness about family planning methods, increasingly more women joining the workforce, and the effectiveness of the government's family planning push to "Stop at Two" for families. By 1980, the TFR was 1.82; by 2000, the TFR was 1.6 and fell to another low of 1.24 by 2015; and by 2018, the TFR was 1.14 (Department of Statistics, Singapore, 2019). This was despite best efforts by the government to encourage procreation. Incentives such as generous baby bonuses, the child development account (CDA or co-savings) scheme, longer paid maternity leave for mothers (up to 16 weeks), introduction of two weeks of government-paid paternity leave for fathers, and childcare fee subsidies for working mothers, were implemented and gradually enhanced. Meanwhile, the government reminded Singaporean families to have "Three or more children if you can afford it" (Saw, 2012, p.215).

The government was worried that with the low TFR and the ageing baby boomers (those born before independence), there would be a strain on social spending, a sluggish economy with fewer economically active Singaporeans, and subsequent pressure on the young to have to bear more of the financial burden in supporting an increasingly ageing population. Between 1965 and 2015, Singapore's population grew from 1.9 million to 5.5 million. The number of citizens, aged 65 and above, has increased rapidly as population growth slows down. The size of this group of citizens (aged 65 years old and above) has doubled from 220,000 in year 2000 to 440,000 in year 2015, and is expected to increase to 900,000 by year 2030 (Government of Singapore, 2017).

In addition, the lifespans of Singaporeans were increasing, with females living up to 84 years old, and males living up to 80 years old, on average. This meant that each Singaporean was expected to live another 15-20 years post-retirement from active work, and would have to depend on others for social 
INTERNATIONAL JOURNAL OF ACADEMIC RESEARCH IN BUSINESS AND SOCIAL SCIENCES Vol. 10, No. 2, Feb, 2020, E-ISSN: 2222-6990 @ 2020 HRMARS

and financial support during that duration, particularly when they did not have adequate support of such nature on their own.

While the government continued its efforts to encourage and support procreation among Singaporeans, two other concurrent efforts had to be done. First, the government had to make changes to the Employment Act to increase the retirement age of older Singaporeans so that more would be kept economically active and occupied even as they were older (Chuang, March 2019).

Second, even for older Singaporeans who had retired, they had to be kept active and engaged in the community through volunteer-led activities. Hence, a massive, community-led initiative, funded by the government, had to be planned and implemented. This was done under the People's Association (PA), a statutory board under the Ministry of Culture, Community and Youth. On average, the PA was allocated an annual estimated budget of S\$1 billion (US\$740 million) for its community-led activities and programs to promote racial harmony and social cohesion, including initiatives for seniors (People's Association, 2017, p.27).

Third, the government had to encourage married adult children to live close to their parents so that it would be easier for these married adult children to also keep an eye out for and play a more active role in taking care of their ageing parents. Hence, the government had to make it more attractive for married adult children to live near their ageing parents through public housing grants for both brand new and resale public flats, as well as re-introducing 3-generation (3G) public flats. These $3 G$ flats were bigger public flats which offered a dual-key option so that the married adult children could live directly next to or adjacent to their ageing parents, yet would still be able to enjoy own private living space (Housing and Development Board, 2017).

Despite these efforts on the part of the government, the challenges of having an ageing population still loomed over their heads. There were still many pioneer, and non-pioneer, seniors who lived away from their children. When one of the senior spouses died, the remaining senior person lived alone, with infrequent visits from their adult children. As a result, the community had to take on a more proactive role in ensuring that such senior persons (pioneers and non-pioneers alike) did not end up in neglect and that at least someone would know of their condition and well-being. Volunteers from voluntary welfare organizations, non-government organizations, and government-funded committees, led house visits to the homes of these senior persons.

However, there was a lack of coordination among these volunteer-led groups and each organization had specific areas of focus and limited funding for sustained outreach and engagement of the senior persons. In addition, the government-funded committees under the PA such as the Active Ageing Committees and Senior Citizens' Executive Committees, focused more on social cohesion and active ageing activities for seniors within the community.

Although the government had many different social and financial assistance schemes to help seniors, not enough of these volunteers were trained to share information about such schemes that the senior person needed to know, or were able to make referrals to the relevant agencies that could follow up with each senior person for the help they needed. The government recognized this was 
INTERNATIONAL JOURNAL OF ACADEMIC RESEARCH IN BUSINESS AND SOCIAL SCIENCES Vol. 10, No. 2, Feb, 2020, E-ISSN: 2222-6990 ¿ 2020 HRMARS

going to be an ongoing challenge for the nation, and hence decided that further government intervention, and funding, was needed.

\section{The Pioneer Generation Office Singapore}

The Pioneer Generation Office (PGO) was set up in August 2014, with the initial intent of engaging pioneers (Singaporeans born on 31 Dec 1949 or earlier, and who became a Singapore citizen by 31 December 1986), and explaining to them about the Pioneer Generation Package (PGP). The PGP cost the Singapore government about S\$9 billion (US\$ 6.7 billion), and was overseen by the Ministry of Finance and the Ministry of Health (Government of Singapore, 2019a). The PGP was meant to recognize the efforts and sacrifices of the pioneer generation of Singaporeans who had toiled hard to make Singapore what it was, fifty years after independence.

Its initial mission was to recruit and train a group of volunteer Pioneer Generation Ambassadors (PGAs) who would go door-to-door, one household at a time, to explain the benefits of the PGP and answer their queries. The role of the PGO, and consequently the PGAs, were expanded to include the engagement of both pioneers and non-pioneer seniors on other senior-related government-funded schemes or programs.

There were 3 components of benefits under the PGP:

\section{Outpatient Care}

- Eligible pioneers would get additional $50 \%$ off subsidized services and medications at all polyclinics and Specialist Outpatient Clinics in the restructured hospitals.

- Enjoy subsidies at participating General Practitioner (GP) clinics and dental clinics under the Community Health Assist Scheme (CHAS).

- Cash of $\$ \$ 1,200$ a year for eligible pioneers who have moderate or severe functional disabilities under the Pioneer Generation Disability Assistance Scheme (PG DAS).

\section{Medisave Top-Ups}

- Eligible pioneers would get an annual Medisave (to fund medical costs from one's personal savings) top-up of between $\mathbf{\$} \$ 200$ to $\$ \$ 800$, for the rest of their lives.

\section{Medshield Life}

- Eligible pioneers would be covered under the Medishield Life (national medical insurance scheme), even those with pre-existing conditions, to help pay for large hospital bills.

- Eligible pioneers would also get special subsidies to ensure that the Medishield Life premiums remain affordable for them.

- Eligible pioneers born in 1934 or earlier would have their Medishield Life premiums fully covered and paid for by the government.

In addition to explaining about the PGP, and making referrals to the PGP for appeals requested by pioneers who were not initially eligible for it, the PGAs also needed to reach out to and explain to the pioneers and non-pioneer seniors, about other senior-related government-funded schemes or 
INTERNATIONAL JOURNAL OF ACADEMIC RESEARCH IN BUSINESS AND SOCIAL SCIENCES

Vol. 10, No. 2, Feb, 2020, E-ISSN: 2222-6990 @ 2020 HRMARS

programs. These other schemes or programs include the GST Vouchers usually allocated from the annual budget, CHAS, the Enhancements for Active Seniors (EASE) Scheme, and the Silver Support Program.

\section{The Pioneer Generation Ambassadors - Going the Last Mile and the Extra Mile}

The PGAs were trained not just to cover the very important last mile in reaching out and explaining various senior-related government-funded schemes and programs to the pioneers and non-pioneer seniors. They were also expected to go the extra mile in helping these pioneers and non-pioneer seniors such as making referrals for them to the social service offices or family service centers should they need financial or social assistance; explain about other schemes or programs that they may enquire about; and even to act as a listening ear or counsellors to these pioneers and non-pioneer seniors who might just be lonely or who might have been neglected by their family members.

It was not easy to recruit PGAs. For a start, the PGAs were mostly older and a substantial proportion (72.7\%) of still active PGAs were 50 years old and above, while only $6.7 \%$ of them are below 30 years old (Pioneer Generation Office, personal communication, October 20, 2017). While this in itself was not a problem, the older PGAs (those aged 50 years old and above) remarked that

(i) the frequent household visits and extended engagements were quite tiring;

(ii) the need to explain the various, and increasingly more, senior-related government-funded schemes and programs was cerebrally challenging as it required substantial understanding of the details of each scheme and program;

(iii) the need to record details of the engagement sessions in English and to have sufficient IT proficiency to key in their post-engagement data with the pioneer or non-pioneer senior residents, was quite challenging; and

(iv) the 6-monthly Currency Assessments on Skills and Knowledge to keep abreast of the changes in senior-related government-funded schemes and programs were quite taxing for them.

Other than the training and knowledge-based requirements as PGAs, the PGAs were considered as volunteers and do not have salaries or employment benefits. They were given transport and meal allowances for the days they carried out their outreach efforts, and this amounted to about S\$10 (US\$7.40) per day. This amount was just enough for one meal and for transport expenses. When any of the PGAs fell ill, they would have to bear their own medical expenses.

In addition, the PGAs would have to be relatively physically fit in order to be able to do their outreach efforts. They had to make household visits to the pioneers or non-pioneer seniors assigned to them either during the day or at night, and sometimes on weekends. It was particularly physically demanding for the PGAs, mostly in their 50 s, to make house visits to private estates such as landed houses which required a lot of walking in addition to the loading weight of their print collaterals and tablet for data entry. While a number of the PGAs were retirees or stay-at-home mothers, a sizeable number of the PGAs had day jobs and had difficulty making the commitment to visit the pioneers and non-pioneer seniors in the evenings or on weekends. 
On top of that, some of the PGAs had lamented that while most households welcomed them, there were some which did not welcome them. It was understandable as a number of the pioneers or nonpioneer seniors were alone during the day, and in the early evenings. While they welcomed having someone come over to spend time and chat with them, their grown-up children would constantly remind their elderly parents not to let strangers into the home, for various reasons. Some cited the fear of being cheated or robbed by strangers, while others did not like having their elderly parents divulge too much information about the family once they started chatting with the PGAs.

PGAs had also shared on instances where the pioneers or non-pioneer seniors they talked to sought their help for financial assistance or social assistance (such as help in communicating with their children, getting them to visit more often, or getting monthly allowance from their grown-up children). However, when more information was sought from these pioneers or non-pioneer seniors about their family background and means to contact their grown-up children, many of them would change their minds and asked the PGAs not to pursue the matter. Hence, while the PGAs were eager and able to help, quite a number of these pioneer and non-pioneer seniors were not willing to divulge personal or family information for follow-up action to be carried out. Among the reasons they cited was that while they would appreciate follow-up assistance, they worried that their children would not agree to share personal family information such as family income.

\section{Discussion - Addressing the Challenges Faced}

Hui Ying recognized that there were several possibilities in addressing the three challenges she had of (i) having had only 1,300 trained PGAs left to carry out the outreach initiatives to seniors; (ii) recruiting, training and retaining more potential PGAs; and (iii) recruiting younger individuals to be trained and retained as PGAs.

While continuing with the current efforts of reaching out to and engaging the pioneers and nonpioneer seniors in Singapore, the PGO was also exploring ways to collaborate with like-minded organisations (whether voluntary welfare organisations (VWOs) or government-based agencies) to promote the PGA program and to close the loop for assistance request such as befriending services or request for medical escorts for pioneers or non-pioneer seniors to go for their medical checks and consultations (Pioneer Generation Office, personal communication, October 20, 2017). Close collaboration with the Social Service Offices or Family Service Centre providers, for instance, would help PGAs make referrals for social or financial assistance more easily for the pioneers or non-pioneer seniors who needed help.

As a result, $\mathrm{PGO}$ piloted a community outreach initiative with the Ministry of Health (MOH), known as the Community Network for Seniors, which was announced by the MOH Ministerial Committee on Aging under the 2015 Action Plan for Successful Aging. The Community Network for Seniors planned to plug the gap in social care and assistance for this group of senior Singaporeans through a "more systematic collaboration between government agencies and community-based stakeholders such as VWOs and grassroots, to leverage on each other's strengths and resources", to jointly support the senior (Ministry of Health, Singapore, 2016). Under this action plan, there would be a small team of 
INTERNATIONAL JOURNAL OF ACADEMIC RESEARCH IN BUSINESS AND SOCIAL SCIENCES Vol. 10, No. 2, Feb, 2020, E-ISSN: 2222-6990 @ 2020 HRMARS

coordinators from different agencies, similar to an inter-ministry and inter-agency task force, that would work together to achieve the following aims:

(a) Expand outreach to a bigger pool of seniors

(b) Link healthcare and social service together to serve seniors better

(c) Engage stakeholders and recruit more resident volunteers to help care for seniors living alone in the community

As the CTO of PGO, Hui Ying needed to ensure that the PGAs were adequately trained to work collaboratively with other like-minded personnel from across the different government agencies and community partners.

Other than VWOs or government-based agencies, it would be possible for PGO to collaborate with institutes of higher learning (IHLS) to (i) train the IHL students; and (ii) deploy the trained IHL students as trained PGAs. Being a PGA may be attractive to this group of IHL students as the allowance was still relatively substantial. In addition, the opportunity to be involved in understanding policies related to seniors, and in engaging this group of senior Singaporeans would prove useful in helping younger Singaporeans better understand social and financial policies affecting a specific demographic group, and engender awareness, empathy and care for seniors.

However, the challenge in getting young Singaporeans to become PGAs was their ability to speak local mother tongue languages and dialects such as Mandarin, Hokkien, Teochew, Cantonese, Malay or Tamil. Older Singaporeans were better able to speak such mother tongue languages and dialects. That was also the reason that more PGAs were older Singaporeans, above the age of 50 years old (72.7\%). As a result, there were more PGAs who were retirees (i.e. those in their late 50 s and in their 60s).

As part of their volunteer retention strategic plan, the PGO was also carrying out a survey known as the 'PGA Happiness Index Exercise' to gather feedback from their current PGAs on how PGO could do better in providing better training for the PGAs and in their effort to continuously provide good outreach and volunteering experience for the PGAs. Part of this effort to do so would include enhancing training provision for the PGAs.

In addition, PGO was also planning to carry out regular analyses on the data collected from the pioneers and non-pioneer seniors that had been engaged, in an attempt to better identify outreach strategies, engagement methods, and information required. Hand-held digital devices and other technological tools could be harnessed for more effective communication, and data collection and analysis.

There were many possibilities in terms of collaboration and strategies to improve training provision as well as outreach and engagement services for seniors in Singapore by the PGO and its PGAs and community partners. What was certain was that the senior population in Singapore was not going to decline soon, and that new and innovative ideas and approaches were needed to ensure this group of Singaporeans were not neglected or sidelined, as the country continues to progress and thrive. More importantly, Hui Ying understood that the PGO and PGAs could not do it entirely on their own 
INTERNATIONAL JOURNAL OF ACADEMIC RESEARCH IN BUSINESS AND SOCIAL SCIENCES

Vol. 10, No. 2, Feb, 2020, E-ISSN: 2222-6990 ¿ 2020 HRMARS

- collaboration and partnerships with like-minded entities were crucial in ensuring the success of such training, outreach and engagement services for seniors in Singapore.

\section{Conclusion}

As of April 2018, the Pioneer Generation Office was renamed the Silver Generation Office. This renaming and repositioning was meant to better support outreach to all Singaporeans aged 65 years and above. In addition, "apart from explaining government policies, Silver Generation Ambassadors will proactively identify seniors who are in need and connect them to active ageing, befriending and aged care services in the community" (Ministry of Health, 2018). The Silver Generation Office (SGO) currently has more than 3,000 volunteers to "engage seniors at home or in community places, to make government policies and schemes as well as community activities and health services more easily accessible" (Agency for Integrated Care, 2016). While the number of volunteers and ambassadors have increased, there is also many more senior-related national schemes and programs that the volunteers and ambassadors would need to fully understand and be able to convey to a growing proportion of seniors in Singapore.

On top of that, as of March 2019, yet another recognition package, the Merdeka Generation Package (MGP), was announced by the Singapore government. Similar to the PGP, the MGP was meant to "thank the Merdeka Generation (MG) for their contributions to (the) nation, and show our care for them in their silver years. It provides benefits to support MG seniors to age actively and purposefully, with better assurance over future healthcare costs. (Government of Singapore, 2019b). The S\$8 billion (US\$ 5.9 billion) MGP would benefit some 500,000 Singaporeans, including those who missed out on the earlier PGP. For the SGO volunteers and ambassadors, this meant that there is now an even larger group of seniors in Singapore to reach out to and engage, and even more information to understand and remember and convey.

\section{Acknowledgement}

The Pioneer Generation Office, Singapore (now known as Silver Generation Office), for the statistics and information pertaining to the PGAs, given upon request and allowed for use with permission.

\section{Corresponding Author}

Dr Intan Azura Mokhtar

Design and Specialised Businesses Cluster, Singapore Institute of Technology

10 Dover Drive, Singapore 138683

Email: intan.mokhtar@singaporetech.edu.sg

\section{References}

Agency for Integrated Care. (2016). Silver Generation Office. Retrieved Mar 16, 2019 from https://www.aic.sg/for-seniors-and-caregivers/silver-generation-office

Chuang, P. M. (2019). Government, unions and employers agree to raise retirement, reemployment age. The Business Times, Mar 6. 
INTERNATIONAL JOURNAL OF ACADEMIC RESEARCH IN BUSINESS AND SOCIAL SCIENCES

Vol. 10, No. 2, Feb, 2020, E-ISSN: 2222-6990 @ 2020 HRMARS

Crampton, A. (2009). Global Aging: Emerging Challenges. The Pardee Papers No.6, Boston, MA: Boston University. Retrieved Mar 16, 2019 from http://www.bu.edu/pardee/files/2009/09/pardee_aging-6-global-aging.pdf

Department of Statistics, Singapore (2019). Singapore Statistics 2019. Retrieved Mar 16, 2019 from https://www.singstat.gov.sg/

Easterbrook, G. (2014). What happens when we all live to 100? The Atlantic, October 2014. Retrieved Mar 16, 2019 from https://www.theatlantic.com/magazine/archive/2014/10/whathappens-when-we-all-live-to-100/379338/

Government of Singapore. (2017). Singapore feeling impact of rapidly ageing population. Retrieved Mar 16, 2019 from https://www.gov.sg/news/content/singapore-feeling-impact-of-rapidlyageing-population

Government of Singapore. (2019a). Pioneer Generation Package. Retrieved Mar 16, 2019 from https://www.pioneers.sg/en-sg/Pages/Overview.aspx

Government of Singapore. (2019b). Singapore Budget 2019 - Merdeka Generation Package. Retrieved Mar 16, 2019 from https://www.singaporebudget.gov.sg/budget_2019/budgetmeasures/merdeka-generation-package

Housing and Development Board. (2017). Types of flats. Retrieved Mar 16, 2019 from https://www.hdb.gov.sg/cs/infoweb/residential/buying-a-flat/resale/types-of-flats

Koh, E. C. (2010). Phases of Singapore's Demographic Development Post World War II. Ethos(7). Retrieved Mar 16, 2019 from https://www.cscollege.gov.sg/Knowledge/Ethos/Issue\%207\%20Jan\%202010/Pages/Phases-ofSingapores-Demographic-Development-Post-World-War-II.aspx

Latimer, J., Davis, T., Bagley, M. C., and Kipling, D. (2011). Ageing science, health care and social inclusion of older people. Quality in Ageing and Older Adults, 12(1), 11-16.

Ministry of Health, Singapore. (2016). Committee of Supply Highlights: Better Health, Better Care, Better Life.

Ministry of Health, Singapore. (2018). Committee of Supply 2018 Factsheet: Beyond Hospital to Community.

Mulders, J. O. (2019). Attitudes about working beyond normal retirement age: The role of mandatory retirement. Journal of Aging and Social Policy, Vol.31. Retrieved Mar 16, 2019 from https://www.tandfonline.com/doi/full/10.1080/08959420.2018.1563473

People's Association. (2017). The People's Association Annual Report 2016/2017. Singapore: People's Association, Sep 27.

Pioneer Generation Office. (2017). Personal communication.

Ross, D. (2010). Ageing and work; An overview. Occupational Medicine, 60, 169-171.

Saw, S. H. (2012). The Population of Singapore. Singapore: Institute of Southeast Asian Studies, 362 pages.

Straudinger, U. M., Finkelstein, R., Calvo, E., and Sivaramakrishnan, K. (2016). A global view on the effects of work on health in later life. The Gerontologist, 56(S2), S281-S292.

United Nations, Department of Economic and Social Affairs, Population Division. (2015). World Population Ageing 2015 (ST/ESA/SER.A/390). Retrieved Mar 16, 2019 from http://www.un.org/en/development/desa/population/publications/pdf/ageing/WPA2015_Rep ort.pdf 
INTERNATIONAL JOURNAL OF ACADEMIC RESEARCH IN BUSINESS AND SOCIAL SCIENCES Vol. 10, No. 2, Feb, 2020, E-ISSN: 2222-6990 @ 2020 HRMARS

Zacher, H., and Rudolph, C. W. (2017). Successful aging at work and beyond: A review and critical perspective. In Age Diversity in the Workplace, pp. 35-64. Published online: 03 Aug 2017. Retrieved Mar 16, 2019 from https://doi.org/10.1108/S1877-636120170000017004

Zacher, H., Kooji, D. T. A. M., and Beier, M. E. (2018). Active aging at work: Contributing factors and implications for organizations. Organizational Dynamics, 47(1), 37-45. 